Extensive investigation of the South Atlantic Ocean by the German Meteor Expedition in 1925-27 did much to advance marine science, and there is little doubt that concerted effort with our new techniques in the Indian Ocean will meet with similar success provided wo give ourselves as much time to learn from it, and avoid too much organization as a pattern of things to come. Perhaps the new venture follows too soon on the International Geophysical Year surveys, but the organization and the problems are being approached very carefully, by the researchminded scientists as well as those who see the need for some campaigning.

The planning and operating of programmes is being done by national committees for oceanic research. Growing interest in them has already sent research ships from the United States and the U.S.S.R. to the Indian Ocoan, and useful observations are also being made by H.M. survey ships and Royal Australian Navy frigates. At the peak of activity, covering the north-easterly and south-westerly monsoons of 1962-
63 , there may be as many as twelve ships working in fairly close co-operation. It is expected that a ship from the United Kingdom will be there, and that she will play an effective part in the programme as well as serving as a base for scientists whose work is likely to be advanced by spocial observations in Indian Ocean conditions.

The Special Committee on Oceanic Research chose Copenhagen and Helsinki for its meetings because many marine scientists were already at Copenhagen to take part in intergovernmental discussions arranged by Unosco, and at Helsinki to participate in the scientific meetings of the International Union of Geodesy and Geophysics. There is much careful and detailed work to do. Those taking part will be heartened by the recent announcemont from the White House of active support to the U.S. contribution for which the National Academy of SciencesNational Research Council is sciontifically responsible. G. E. R. DEACON

1 See Nature, 180, 894 (1957).

\title{
WATER RESOURCES IN THE UNITED STATES
}

$\mathrm{T}$ HE pressure of growing populations with rising standards of living increasingly brings water into focus as a basic raw material in need of both study and conservation. Nowhere is this realized more fully than in the United States, where development in a wide range of activities is at present limited by water supplies. As a result of Senate Resolution No. 48 of the eighty-sixth Congress of the United States a Select Committee on National Water Resources was set up in 1959 to study the extent and character of water resources activities required to provide the future quantity and quality of water needed for all segments of the economy in the United States.

Headed by Senator Robert S. Kerr from Oklahoma, this Committee has now been at work during the past year and has within a short space of time produced an impressive array of reports on a wide variety of hydrological topics*. Although confined to the United States, many of these reports have relevance to water problems that the United Kingdom and the Commonwealth face, and it is the aim of this review to indicate the coverage of the reports so far available together with their main conclusions. The speed with which the Select Committee has produced a great body of useful basic material is notable, and this has been achieved by the Committee calling upon existing authorities and organizations to provide the appropriate hydrological information.

* Reports available in June 1960 and printed for the use of the Select Committee on National Water Resources of the United State Senate pursuant to Senate Resolution No. 48 of the Eighty-Sixth Congress. Government Printing Office, Washington:

No. 2, Reviews of National Water Resources during the Past Fifty Years, October 1959 ; No. 3, National Water Resources and Problems January 1960 ; No. 4, Surface Water Resources of the United States, January 1960 ; No. 7, Future Water Requirements for Municipal Vse, January 1960 ; No. 9, Pollution Abatement, January 1960 ; No. 12 Land and Water Potentials and Future Requirements for Water December 1959; No. 13, Estimated Water Requirements for Agricultural Purposes and their Effects on Water Supplies, December 1959 ; No. 16, Flood Problems and Management in the Tennessee River Basin, December 1959 ; No. 19, Water Resources of Alaska, January 1960; No. 20, Water Resources of Hawaii, January 1960 Weather Modifleation, January 1960 ; No. 23, Evaporation ; No. 22, and Seepage Control, December 1950; No. 24, Water Quality Manageand secpage control, December 1950 ; No. 24, Water Quality Manageological Analysis, November 1959; No. 26, Saline Water Conversion, November 1959; No. 27, Application and Effects of Nuclear Energy, December 1959 ; No. 28, Water Resnurces Research Needs, February 1960 .
As a result the reports fall into a number of natural groups largely related to the reporting department, the stage being set by No. 2, where the Legislative Reference Service of the Library of Congress reviews and summarizes the work of more than 20 commissions or committees which have investigated national water policies and problems in the United States during the past fifty years. With fow exceptions provious study groups have paid little attention to the questions which the Senate has placed before the present Select Committee; notably, "How much water development is needed? When is it needed? Where is it needed? What should be the pattern of water development? What amounts of water will be required in relation to various levels of population and economic activity? What are the economic limits of water development ?"

One of the first authorities that the Committee turned to for basic information was the Geological Survey; this department has prepared reports Nos. 3 and 4 dealing with the national water resources, both surface and underground, and related problems. In addition to furnishing quantitative information showing the use of water, the availability of water, and the amount of storage required to maintain certain rates of river-flow, report No. 3 identifies and discusses water problems in the fields of supply, variability, distribution, natural quality, pollution and floods. The report indicates that almost every part of the United States faces current or potential water problems. An estimated water use in 1960 of 250 thousand million gallons of fresh water a day is projected to rise to 600 thousand million gallons a day by 1980 . This fortunately still falls considerably short of the estimated manageable supply of 1,160 thousand million gallons a day, but it does moan that in many areas much water will have to be used over and over again and that pollution abatement becomes critical. Report No. 4 presents in tabular and map form the surface water resources of each State. Data on avorago, maximum, and minimum discharges in cubic feet per second, and average annual run-off in acre-feet at key-points within each State are given, together with a very interesting set of maps showing 
comparative river-flows. This report really summarizes in a most effective way the annual surface water supply papers of the United States.

Reports Nos. 7, 9 and 24 emanate from the Department of Health, Education and Welfare ; these deal with the future water requirements for municipal use, pollution abatement, and water quality management respectively. At the turn of the century about 30 million people in the United States had a municipal water supply and were using some 3 thousand million gallons a day. In 1954, the number supplied had increased to more than 100 million people and these were using 16 thousand million gallons of water daily. This is an average rate of nearly 150 gallons per capita a day with maxima of more than 200 gallons a day per person in some towns. These figures of course include both trade and domestic use. Report No. 7 shows that with medium rates of growth of population this level of water consumption will probably rise to 29 thousand million gallons a day by 1980 and 43 thousand million gallons a day by the year 2000 . With a high rate of population increase the figures would be 33 thousand millions by 1980 and 58 thousand millions by the year 2000. Assuming that certain stimulants of municipal use continue to occur and taking a maximum population increase, a ceiling of 43 thousand millions by 1980 and 88 thousand million by the year 2000 is theoretically possible. Daily consumption per capita might then be of the order of 225 gallons. If cities are to continue to supply their residents with adequate supplies of clean fresh-water much forethought is clearly going to be necessary.

Report No. 9 from the same department deals with pollution, and directs attention clearly to the magnitude of the problem which confronts the United States in its search for clean water. In addition to the normal problems of disposal of sewage and ordinary industrial wastes, many new types of pollution have recently appeared. Synthetic organic chemicals, radioactive substances and newly identified viruses and other disease-producing micro-organisms are the problems of principal concern.

The third report from this Department, No. 24 in the series, deals with water quality management. This discusses water quality and quantity requirements for various purposes, the limitations of streams as waste carriers, and the economics of water pollution. It points out that the growing demands for water and limitations on developable supplies inevitably imply a greater re-use of river-flows, and it further emphasizes that many areas are rapidly running out of clean water.

The next group of reports, Nos. 12, 13 and 28, have been prepared by the Department of Agriculture, and these deal respectively with land and water potentials and future requirements for water, estimated requirements of water for agricultural purposes, and the needs of water resources research. Report No. 12 confirms that the use of water for agricultural purposes is the largest consumer of water in the United States, even though in recent years withdrawals of water for industrial purposes have exceeded those for irrigation. Generally, however, more than half the water withdrawn for irrigation is consumed by evaporation and transpiration, while less than a tenth of the water withdrawn for industrial purposes is lost. Agriculture also becomes of increasing significance in the water problem because of the growing trends in the United States to irrigate the humid areas as a means of increasing yields of crops. The report shows that the diversion and storage of water for irrigation in 1954 was 195 million acre-feet, of which 115 million acre-feet were actually used for irrigation. On the basis of projections of medium-level populations the Department of Agriculture estimates that requirements of water for irrigation in 1980 will amount to 181 million acre-feet for storage and diversion with 114 million acre-feet actually used for irrigation. This somewhat surprising and welcome reduction emerges as a result of assuming the application of known improved methods of water management. Failing, however, the adoption of these improved methods of storing, transporting and using irrigation water, enormous additional amounts of water would be required.

In addition to the direct use of water for agricultural production there are a number of other programmes in the United States for the conservation and development of agricultural land which affect water resources. These include the run-off and waterflow retardation schemes, soil erosion prevention, and watershed improvement. Report No. 13 deals with the implications of these: at present programmes for land treatment have been put into effect on some 18 per cent of the crop-land, pastures and woodlands. This should increase to 32 per cent by 1980 and 52 per cent by the year 2000 . These programmes will, it is thought, deplete downstream flows by 4.5 million acre-feet in 1980 and by 7.8 million acre-feet in the year 2000. These amounts are small in comparison with the requirements of irrigated agriculture and are not thought to be problematical. Report No. 28, also prepared by the Department of Agriculture, lists the research which will be needed if the best use of water is to be made in the production of essential agricultural and forest products. This report shows a welcome awareness of the importance of water as a prime raw material worthy of care and conservation.

The next group of reports, Nos. 22 and 25, emanate from the United States Weather Bureau and deal with weather modification, river forecasting and hydrometeorological analysis. In the broadest sense weather modification includes all man-made changes in natural conditions of weather and climate. It applies to a wide variety of atmospheric phenomena ranging in scale from micro- to macro-conditions. Report No. 22, however, deals primarily with cloud modification as a means for increasing rainfall. As only 5-15 per cent of the available moisture in a cloud system reaches the ground during a rainstorm, it is obvious that even a slight increase in the amount of precipitation could have a tremendous effect on water supplies. It has been held that this possibility therefore justifies the very considerable expense that has so far been incurred in artificial rain-making. To date, however, the Weather Bureau has had to admit that much uncertainty still remains in the results of cloud seeding and in the practical utility of present methods of artificially increasing rainfall. The Weather Bureau also has the responsibility of forecasting river-flows for the purpose of reducing flood damage and the prevention of loss of life from floods, and report No. 25 deals with future needs and possibilities for improvements in this service as a means of increasing the usefulness of available water supplies.

A further group of reports, Nos. 19-21, 23 and 26, emanate from the Department of the Interior. Nos. 19 and 20 are straightforward accounts of the water 
resources of Alaska and Hawaii respectively. These two States have been considered separately from the continuous area of the United States as so many of their water problems are different. The report on Alaska shows that four main problems will hinder water supply development in the far north : these are the winter freeze and permafrost, the presence of glacial flour, impervious consolidated rocks limiting ground-water storage, and problems of waste disposal in the winter months. It is interesting to note that irrigation is being employed in Alaska and that eventually this should grow to 50,000 acres. The potential of water-power is enormous and more than 13 million $\mathrm{kW}$. could be developed at some 168 sites. In Hawaii the main problem appears to be the unequal distribution in both time and place of the precipitation, and this produces recurring water shortages despite the abundant rainfall. Immediate problems are not, however, incapable of solution.

Reports Nos. 21 and 23 may be taken together as these deal respectively with evapo-transpiration reduction, and evaporation reduction and seepage control. Evapo-transpiration is the transfer of water to the atmosphere from plants and other surfaces as a result of normal evaporation of precipitation, and also transpiration, which is the release of water vapour to the atmosphere in the process of photosynthesis. The Department of the Interior reports that opportunities for improved yields of water through management of vegetation appear favourable on some 15 per cent of the area of 17 western States; with a possibility of increasing water-yields in amounts ranging from about 1 to 6 inches in certain forest areas of heavy precipitation to as low as $0.25 \mathrm{in}$. in the pinon-juniper regions. No increase at all is possible on the semi-arid lands covered with grass and shrub which make up the greater portion of the southwest United States. The Department has also investigated the effect of losses from phreatophytes, the water-loving 'well plants' which cause a major loss of water along rivers in the western States. These cover some 16 million acres and discharge 20-25 million acre-feet of water into the atmosphere annually. By controlling the phreatophytes it should be possible to save some 6 million acre-feet of water by 1960 and up to 12 million acre-feet by the year 2000 . Much water is also lost from irrigation works by seepage and evaporation, and it is estimated that improvements in irrigation water conveyance works could save up to 4.5 million acre-feet by 1980.

Report No. 26 is concerned with the increasingly important topic of saline water conversion. The search for means of tapping this obvious unlimited source of water has taxed the ingenuity of man for many centuries, and practical methods for desalinization of ocean water in small quantities have been used on ships for more than a century. Attention has more rocontly boon turned to the construction of large-scale land-based plants. A programme of research was launched in the United States in 1952 and further onlarged in 1955. In 1958 Congress authorized the construction of large-scale experimental demonstration plants, and this programmo is now under way. In spite of rising prices the cost of converting sea and brackish water to fresh is continually being lowered. Before the Second World War it stood at 4 dollars upwards per thousand gallons : the new experimental plants should bo converting saline water to fresh for less than a dollar per thousand gallons, while processes now in the laboratory stage give promise of conversion-rates below 50 cents per thousand gallons. This report details all the current and proposcd fundamental research, and is a real mine of information for those concerned with this problem.

Finally, there are two other reports of interest : from the Tennessee Valley Authority comes No. 16 on flood problems and management in the Tennessee River Basin, and from the Atomic Energy Commission there is No. 26 dealing with the application and effects of nuclear energy. The flood problem is the converse of the problem of water shortage and, like the United Kingdom, the United States has had in most parts a multiplicity of authoritios doaling separately with problems which are really integrated. Programmes for run-off and water-flow retardation and prevention of soil erosion have been the responsibility of the Department of Agriculture, downstream flood-control works have been in charge of the Corps of Engineers : reclamation work falls to the Bureau of Reclamation. Other authoritios are responsible for the devolopment of power, public water supply, irrigation and so on. In the Tennessee River Basin, however, there is an example of an integrated river basin developmont which is a model of its kind. Here the Authority covers an area of about 40,000 sq. miles and has in its charge all aspects of the hydrological cycle. It was therefore invited to present to the Solect Committee any suggestions as to how its experience might be applied to the major water problem in the United States. In report No. 16 it has some interesting recommendations, more particularly in the sphere of development control in flood plain aroas.

The particular water needs and problems arising from the development of atomic energy are dealt with in report No. 27 prepared by the Atomic Energy Commission. It is not thought that the requirements and applications of nuclear technology will have any major effect or impact on the development of water resources up to 1980 , but the need to recognize the importance of control of water-dispersed waste radioactive products is stressed.

It will be clear that the 600 pages and innumerable diagrams, maps and tables in these 18 reports present a unique and up-to-date picture of the water problems facing the United States. The willingness to look ahead, initially to 1980 and then beyond to the year 2000 , at low-, medium- and high-level population densities reveals an awareness of the increasing importance of water in the future; and of the necessity for the present generation to plan for the water needs of the next. In contrast, the British Central Advisory Water Committee in its recent reports was not prepared to look in any detail beyond 1965-which is almost upon us already. A comparison between the two sets of reports also reveals a quite different attitude of mind and approach to essentially the same problems-notably in the case of irrigation in the humid areas. It is to be hoped that the United States Senate Committee reports will become known in Great Britain to all those concerned with the great variety of aspects of the hydrological cycle; notably watershed management, storage of water, supply of water, control of the quality of water, pollution, saline convorsion, and irrigation. The roports throw much new light on the increasingly important problem of water conservation.

W. G. V. BaLchiN 